\title{
Genetic diversity of the African geocarpic legume Kersting's groundnut, Macrotyloma geocarpum (Tribe Phaseoleae: Fabaceae)
}

\author{
R.S. Pasquet ${ }^{\mathrm{a}, *}$, G. Mergeai ${ }^{\mathrm{b}}$, J.-P. Baudoin ${ }^{\mathrm{b}}$ \\ a IRD, BP 11416 Niamey, Niger \\ ${ }^{\mathrm{b}}$ Phytotechnie des Régions Intertropicales, Faculté des Sciences, Agronomiques, 5030 Gembloux, \\ Belgium
}

Received 21 May 2001; accepted 19 November 2001

\begin{abstract}
A survey of allozyme variation in Kersting's groundnut [Macrotyloma geocarpum (Harms) Maréchal and Baudet] was undertaken by examining 19 enzymes systems encoding 32 putative loci in 18 domesticated accessions and two wild accessions. No variation was found within and among domesticated accessions as well as within and between both wild accessions. However, very high genetic distance between wild and domesticated accessions suggests that they should be assigned to two different species.

(C) 2002 Elsevier Science Ltd. All rights reserved.
\end{abstract}

Keywords: Macrotyloma geocarpum; Phaseoleae; Fabaceae; Isozyme polymorphism; Genetic diversity

\section{Introduction}

The Kersting's groundnut, Macrotyloma geocarpum (Harms) Maréchal and Baudet (Fabaceae: Phaseoleae), is an African legume crop cultivated on a small scale in West Africa. The crop is rapidly disappearing from traditional food production, evidenced by the fact that, except for some limited areas, Kersting's groundnut is now

* Corresponding author. Present address: IRD, ICIPE, PO Box 30772, Nairobi, Kenya. Fax: +254-2860-110.

E-mail address: rpasquet@icipe.org (R.S. Pasquet). 
solely cultivated by elderly people for religious purposes (Amuti, 1980; Mergeai, 1993; Tamini, 1995).

Harms (1908) described Kerstingiella geocarpa Harms from domesticated material collected in Togo during years 1905 and 1907 by H. Kersting, a German colonial civil servant. Two years later, Chevalier (1910a) described Voandzeia poissoni A.Chev. from material collected in Benin. However, a few months later, Chevalier (1910b) recognized that his plant was identical to the one described by Harms. Then Stapf (1913) recorded the plant from Nigeria, and Chevalier (1913) was able to review the topic: $K$. geocarpa was cultivated from Mali to Nigeria through Burkina Faso, Ghana, Togo and Benin (ca. $1500 \mathrm{~km}$ from West to East), and morphological diversity was low (three colors of seeds only).

Pellegrin (1923) described a new species from the same genus, Kerstingiella tisserantii from Central African Republic. Hepper (1963), while collecting new material from North Cameroon, identified this taxon as the wild relative of $K$. geocarpa and reduced it to a varietal rank: K. geocarpa var. tisserantii (Pellegrin) Hepper. Hepper did not observe flowers from living wild plants, but he did not doubt of the very close morphological similarity of the two taxa. However, after the transfer of genus Kerstingiella to genus Macrotyloma (Maréchal and Baudet, 1977; Verdcourt, 1978), Verdcourt (1982) pointed out the striking morphological differences between both taxa and was not convinced of their conspecificity.

Nevertheless, it seems that the wild form has not been collected since 1963 by Hepper and that the herbarium records were limited to those from Tisserant and Hepper. No biosystematic studies were undertaken since Hepper's morphological work on living material. The purpose of this study was to assess genetic diversity within wild and domesticated Kersting's groundnut and relationships between the two taxa on the basis of new collected materials, using isozyme electrophoresis.

\section{Materials and methods}

\subsection{Plant material}

Allozyme diversity was assayed from 18 domesticated accessions and two wild accessions (Table 1). Domesticated accessions originated from West Burkina Faso and North Togo. Accessions from each country included accessions with white, black and gray seeds. Accessions from Burkina Faso and Cameroon are from the collection held by Institut de Recherche pour le Développement (Montpellier, France) while accessions from Togo are from the collection held in Gembloux Agricultural University (Belgium). For wild accession V203, a herbarium specimen collected in the original locality of Cameroon is deposited in Kew and bears the number Pasquet $500(\mathrm{~K})$ (Figs. 1 and 2).

\subsection{Isozyme electrophoresis}

The methods for sample preparation, horizontal starch gel electrophoresis, and enzyme staining are described in Pasquet (1999). Seed extracts were used throughout 
Table 1

Accessions studied

\begin{tabular}{|c|c|c|c|}
\hline Accession & Country & Latitude and longitude & Locality \\
\hline \multicolumn{4}{|c|}{ Domesticated accessions } \\
\hline GP 579 & TGO & $10^{\circ} 45 \mathrm{~N}^{\circ} 33 \mathrm{E}$ & Natongou \\
\hline GP 580 & TGO & $10^{\circ} 46 \mathrm{~N} 0^{\circ} 17 \mathrm{E}$ & Pana \\
\hline GP 581 & TGO & $10^{\circ} 46 \mathrm{~N} 0^{\circ} 17 \mathrm{E}$ & Pana \\
\hline GP 582 & TGO & $10^{\circ} 40 \mathrm{~N} 0^{\circ} 02 \mathrm{E}$ & Tami \\
\hline GP 583 & TGO & $10^{\circ} 36 \mathrm{~N}^{\circ} 23 \mathrm{E}$ & Nagbéni \\
\hline GP 611 & TGO & $9^{\circ} 56 \mathrm{~N} 1^{\circ} 03 \mathrm{E}$ & Atetou \\
\hline GP 612 & TGO & $9^{\circ} 53 \mathrm{~N} 1^{\circ} 05 \mathrm{E}$ & Défalé \\
\hline GP 613 & TGO & $9^{\circ} 53 \mathrm{~N} 1^{\circ} 05 \mathrm{E}$ & Défalé \\
\hline GP 616 & TGO & $9^{\circ} 31 \mathrm{~N} 1^{\circ} 03 \mathrm{E}$ & Djambé \\
\hline GP 620 & TGO & $9^{\circ} 53 \mathrm{~N} 0^{\circ} 31 \mathrm{E}$ & Katchamba \\
\hline GP 622 & TGO & $9^{\circ} 47 \mathrm{~N} 1^{\circ} 03 \mathrm{E}$ & Kidjaboun \\
\hline HV 1 & HVO & & Marché Bobo Dioulasso \\
\hline HV 2 & $\mathrm{HVO}$ & $11^{\circ} 37 \mathrm{~N} 4^{\circ} 40 \mathrm{~W}$ & Fara \\
\hline HV 3 & $\mathrm{HVO}$ & 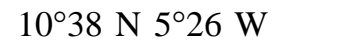 & Outourou \\
\hline HV 4 & $\mathrm{HVO}$ & $11^{\circ} 03 \mathrm{~N} 5^{\circ} 15 \mathrm{~W}$ & Mahon \\
\hline HV 5 & $\mathrm{HVO}$ & $11^{\circ} 50 \mathrm{~N} 3^{\circ} 20 \mathrm{~W}$ & Mana \\
\hline HV 6 & HVO & $11^{\circ} 05 \mathrm{~N} 4^{\circ} 35 \mathrm{~W}$ & Tiara \\
\hline HV 7 & $\mathrm{HVO}$ & $12^{\circ} 30 \mathrm{~N} 3^{\circ} 25 \mathrm{~W}$ & Passakongo \\
\hline \multicolumn{4}{|c|}{ Wild accessions } \\
\hline V 202 & CMR & $808 \mathrm{~N} 1335 \mathrm{E}$ & Nigba \\
\hline V 203 & CMR & $903 \mathrm{~N} 1331 \mathrm{E}$ & km 6 Ngong $\rightarrow$ Garoua \\
\hline
\end{tabular}

$\mathrm{CMR}=$ Cameroon; $\mathrm{HVO}=$ Burkina Faso; TGO=Togo.

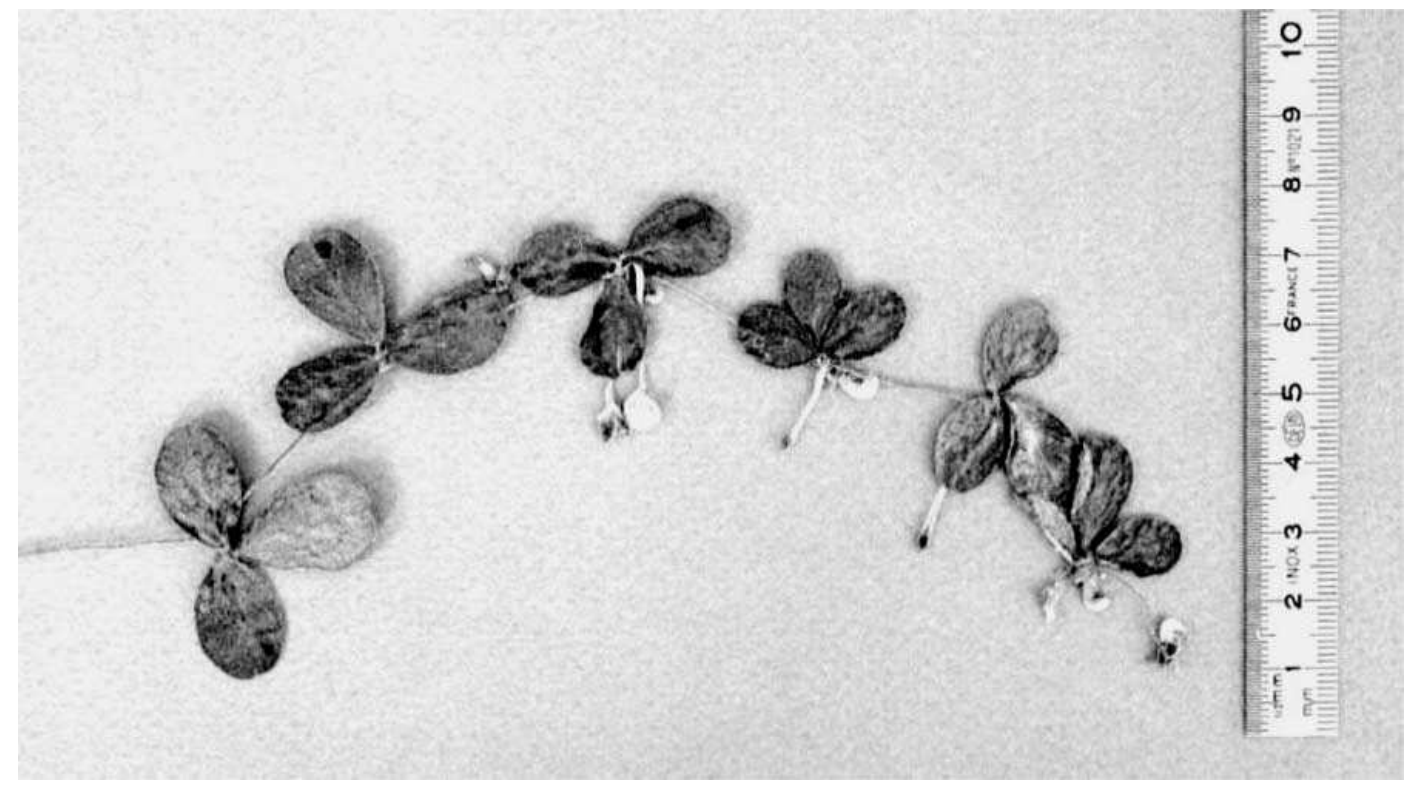

Fig. 1. Pasquet $500(\mathrm{~K})$ herbarium specimen. 


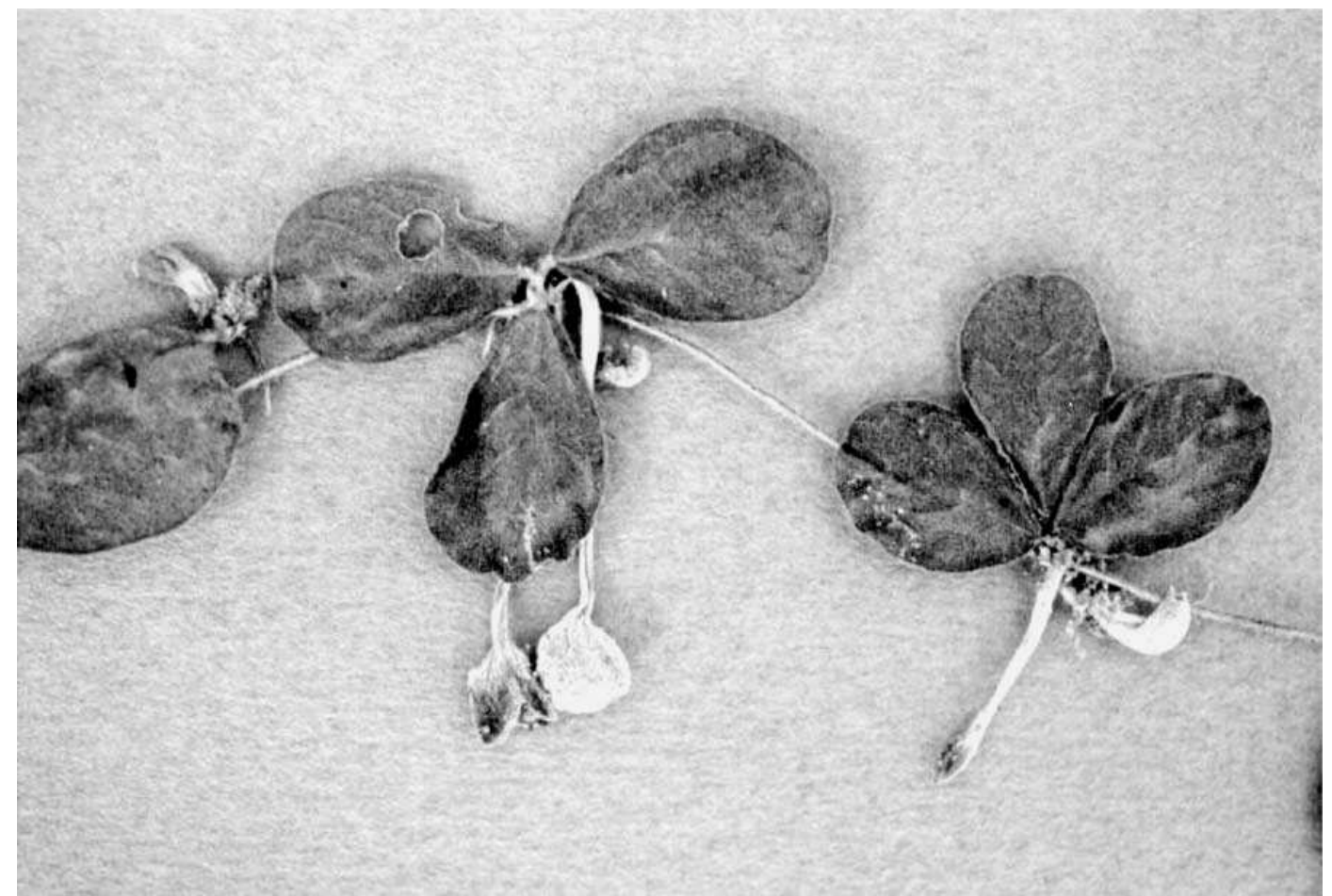

Fig. 2. Pasquet $500(\mathrm{~K})$ herbarium specimen: flower and fruit.

the study, with the exception of $\alpha \mathrm{EST}$, GOT, $\beta \mathrm{GLU}$, and SOD for which leaf extracts were used. Seeds were imbibed overnight and cotyledons were then ground in water, while young leaf tissue was ground in $0.1 \mathrm{M}$ Tris- $\mathrm{HCl}, \mathrm{pH} 7.5,5 \%$ sucrose, $0.1 \%$ mercaptoethanol (Wendel and Weeden, 1989). All isozymes were assayed in the citrate/histidine $\mathrm{pH} 6.0$ buffer system (electrode buffer: $0.41 \mathrm{M}$ citrate $\mathrm{pH}$ 6.0; gel buffer: $5 \mathrm{mM}$ L-histidine mono $\mathrm{HCl}, \mathrm{pH} 6.0$ ), and the gel consisted of $14 \%$ starch.

Nineteen enzyme systems revealing 32 putative loci were screened, namely, alcohol dehydrogenase (ADH), aminopeptidase (AMP), catalase (CAT), NADH diaphorase (DIA), endopeptidase (ENP), esterase (EST), formate dehydrogenase (FDH), fluorescent esterase (FLE), $\beta$-glucosidase ( $\beta$ GLU), glutamate oxaloacetate transaminase (GOT), isocitrate dehydrogenase (IDH), malate dehydrogenase (MDH), malic enzyme (ME), mannose phosphate isomerase (MPI), phosphoglucomutase (PGM), phosphogluconate dehydrogenase (PGD), phosphoglucose isomerase (PGI), shikimate dehydrogenase (SDH), and superoxyde dismutase (SOD). Enzyme-specific staining was carried according by Wendel and Weeden (1989) using either alanine$\beta$-naphtylamide or leucine- $\beta$-naphtylamide for AMP, and 4-methyl-umbelliferyl compounds for FLE and $\beta$ GLU.

For each enzyme system, the presumed loci encoding the most anodally migrating isozyme were designated ' 1 '; with additional loci numbered sequentially in order of decreasing electrophoretic mobility. For each isozyme, the most common domesticated allozyme and respective allele has been designated as 100 and the other allozymes have been measured in millimeters in relation to that standard. This procedure was the same as the one utilized by Pasquet (1999).

For each domesticated accession, three sets of data were considered. Each set of 
data was obtained from a single seed. The seed was imbibed overnight and then sliced in two parts. Approximately two-thirds of the cotyledons were used for up to 15 seed enzyme systems. The germ attached to the remaining third of the cotyledons was germinated to produce a plant used for the 4 leaf enzyme systems and for some enzyme systems checkable in both seeds and leaves.

Due to a low number of wild seeds available, only two sets of data were considered for the wild accessions. Smaller wild accessions seeds imposed to use two or three different seeds to fulfill a set of data. As wild plants cultivated in Niamey did neither flower nor produce seeds, original seeds were used for electrophoresis of wild material.

Allozyme composition of each variety was determined at 32 presumed isozyme loci. Genetic variability was assessed using the proportion of polymorphic loci $(P)$, the mean number of alleles among all loci $(A)$, and among polymorphic loci $\left(A_{\mathrm{p}}\right)$, and the total diversity $\left(H_{\mathrm{t}}\right)$. Total diversity was partitioned into the weighted average diversity within subspecies $\left(H_{\mathrm{s}}\right)$, and between the subspecies gene diversity $\left(D_{\mathrm{st}}\right)$. These parameters are related by the expression $H_{\mathrm{t}}=H_{\mathrm{s}}+D_{\mathrm{st}}$. The proportion of total allelic diversity found among subspecies $\left(G_{\mathrm{st}}\right)$ was calculated as the ratio $D_{\mathrm{s} t} / H_{\mathrm{t}}$ (Nei, 1973). The genetic distances of Nei (1972) were calculated between accessions.

\section{Results and discussion}

\subsection{Isozyme patterns}

The 19 enzyme systems screened revealed 32 scorable loci. ADH, CAT, ENP, FDH, IDH, ME, MPI, and PGD appeared as single bands whereas DIA and SDH appeared as double bands (with the most anodal band being more strongly stained in both enzyme systems). GOT, $\beta$ GLU, and PGM yielded two bands, supposed to be products of different loci. SOD appeared as one strong fast band and one weakly stained slow band. AMP, $\alpha E S T$ and FLE yielded three bands, the fast AMP band and the fast FLE band being poorly stained. MDH1 and MDH2 appeared as a set of three bands formed by two homodimers and one heterodimer, while MDH3 was a single slow band. In the same way, PGI1 and PGI2 products appeared as a set of three bands formed by two homodimers and one heterodimer, the fast band being poorly stained.

\subsection{Diversity}

For the 19 enzymes, an estimated 14 polymorphic loci (approximately 0.7 loci per enzyme system) and 50 alleles were resolved. A summary of the loci and alleles resolved in wild and domesticated group of accessions is provided in Table 2. Consequently, as a species, our sample of $M$. geocarpum (wild+domesticated) has a moderately high estimated heterozygosity $H_{\mathrm{t}}=0.180$ (Nei, 1973). However, although the species looks variable (proportion of polymorphic loci $P=0.44$, mean number of alleles among all loci $A=1.56$ and among polymorphic loci $A_{\mathrm{p}}=2.0$ ), no diversity 
Table 2

Allelic frequencies in wild and domesticated group of $M$. geocarpum accessions for each group. The number of accessions studied is given in parentheses

\begin{tabular}{|c|c|c|c|}
\hline Isozyme loci and alleles & Total (20) & Domesticated (18) & Wild (2) \\
\hline Adh 100 & 1 & 1 & 1 \\
\hline Ampl 100 & 0.9 & 1 & 0 \\
\hline 98 & 0.1 & 0 & 1 \\
\hline Amp2 102 & 0.1 & 0 & 1 \\
\hline 100 & 0.9 & 1 & 0 \\
\hline Amp3 100 & 0.9 & 1 & 0 \\
\hline 0 & 0.1 & 0 & 1 \\
\hline Cat 100 & 1 & 1 & 1 \\
\hline Dia 100 & 0.9 & 1 & 0 \\
\hline 96 & 0.1 & 0 & 1 \\
\hline Enp 100 & 1 & 1 & 1 \\
\hline Est1 112 & 0.1 & 0 & 1 \\
\hline 100 & 0.9 & 1 & 0 \\
\hline Est2 108 & 0.1 & 0 & 1 \\
\hline 100 & 0.9 & 1 & 0 \\
\hline Est3 100 & 0.9 & 1 & 0 \\
\hline 92 & 0.1 & 0 & 1 \\
\hline$F d h 100$ & 1 & 1 & 1 \\
\hline Fle1 104 & 0.1 & 0 & 1 \\
\hline 100 & 0.9 & 1 & 0 \\
\hline Fle2 102 & 0.1 & 0 & 1 \\
\hline 100 & 0.9 & 1 & 0 \\
\hline Fle3 100 & 1 & 1 & 1 \\
\hline BGlu1 100 & 0.9 & 1 & 0 \\
\hline 96 & 0.1 & 0 & 1 \\
\hline BGlu2 100 & 0.9 & 1 & 0 \\
\hline 96 & 0.1 & 0 & 1 \\
\hline Got1 100 & 0.9 & 1 & 0 \\
\hline 98 & 0.1 & 0 & 1 \\
\hline Got2 100 & 1 & 1 & 1 \\
\hline Idh 100 & 0.9 & 1 & 0 \\
\hline 92 & 0.1 & 0 & 1 \\
\hline Mdhl 100 & 0.9 & 1 & 0 \\
\hline 92 & 0.1 & 0 & 1 \\
\hline Mdh2 100 & 0.9 & 1 & 0 \\
\hline 92 & 0.1 & 0 & 1 \\
\hline Mdh3 100 & 1 & 1 & 1 \\
\hline Me 106 & 0.1 & 0 & 1 \\
\hline 100 & 0.9 & 1 & 0 \\
\hline Mpi 100 & 1 & 1 & 1 \\
\hline Pgd 100 & 1 & 1 & 1 \\
\hline Pgil 103 & 0.1 & 0 & 1 \\
\hline 100 & 0.9 & 1 & 0 \\
\hline Pgi2 100 & 1 & 1 & 1 \\
\hline Pgml 100 & 1 & 1 & 1 \\
\hline Pgm2 100 & 1 & 1 & 1 \\
\hline Sdh 100 & 1 & 1 & 1 \\
\hline Sod1 100 & 1 & 1 & 1 \\
\hline Sod2 108 & 0.1 & 0 & 1 \\
\hline 100 & 0.9 & 1 & 0 \\
\hline
\end{tabular}


was found within accessions, among the domesticated accessions, and between the two wild accessions. If we partition the whole observed allozyme diversity into the weighted average diversity within wild and domesticated group of accessions (Nei, 1973), then the intra group diversity was $H_{\mathrm{s}}=0$, the diversity between subspecies was $D_{\mathrm{st}}=H_{\mathrm{t}}=0.180$, and proportion of total allelic diversity found among both group was $G_{\mathrm{st}}=D_{\mathrm{st}} / H_{\mathrm{t}}=1.0$.

The total absence of diversity in domesticated Kersting's groundnut is astonishing. This is especially surprising because the Kersting's groundnut domesticated accessions studied originated from two different areas ca. $600 \mathrm{~km}$ apart, which can be considered to cover the whole area of distribution of the domesticated variety. Such a situation has never been encountered in cultivated plants (Doebley, 1989), especially within tropical legumes (Kiang et al., 1987; Schinkel and Gepts, 1989; Singh et al., 1991; Panella and Gepts, 1992; Potter and Doyle, 1992; Vaillancourt et al., 1993; Pasquet, 1999; Pasquet et al., 1999) where diversity was sometimes considered as really low. The lowest diversity was observed in domesticated Bambara groundnut where allozyme diversity values as low as 0.052 for $H_{\mathrm{t}}, 0,17$ for $P$, and 2,14 for $A_{\mathrm{p}}$ were reported, but domesticated Bambara displayed a comparatively high within population diversity $H_{\mathrm{s}}=0.033$, with $D_{\mathrm{st}}=0.019$ and $G_{\mathrm{st}}=0.365$ (Pasquet et al., 1999). As for Bambara groundnut, we may assume that an inbred breeding system due to almost chasmogamous flowers might have reduced the diversity of domesticated Kersting's groundnut over and over during thousands of generations. However a very strong genetic bottleneck during the initial domestication process might also be involved in this reduction of diversity. Weeden et al. (1996) used the term 'extreme bottleneck' to describe the low diversity of domesticated cowpea compared to wild cowpea (all perennial subspecies included), but the term should be applied more accurately to Kersting's groundnut.

Wild Kersting's groundnut is known from Cameroon to Central African Republic. Therefore, the two populations studied here were representative of only half of the longitudinal extension of the taxon but were representative of the whole of its latitudinal extension: both wild accessions originated from areas located ca. $150 \mathrm{~km}$ apart. Therefore, the lack of diversity within wild Kersting's groundnut is also surprising. However, the low number of seeds studied can explain this lack of diversity, and do not allow to infer relevant conclusions regarding wild Kersting's groundnut diversity. In other legumes, like wild cowpea or wild Bambara groundnut, identical profiles were already recorded in plants from very distant provenance. In Bambara groundnut for example, although the number of plants studied allowed to detect variability in all wild populations (Pasquet et al., 1999), the examination of raw data regarding the 14 polymorphic isozyme loci observed within wild populations showed that identical genotypes were encountered in populations located between $6^{\circ} 35 \mathrm{~N}$ and $10^{\circ} 35 \mathrm{~N}$, just like our two wild Kersting's groundnut accessions.

\subsection{Interrelationships between domesticated and wild Kersting's groundnut}

The main result of this study may be the high genetic distance (Nei, 1972) observed between the domesticated form and the wild form, i.e. 0.827. This value 
is much higher than 0.4, which is the average Nei (1972) distance for populations of congeneric species (Crawford, 1989). In the genus Vigna which also belongs to the Phaseoleae tribe as does the genus Macrotyloma, distances higher than 0.8 were always reported between species (Vaillancourt and Weeden, 1993; Pasquet and Vanderborght, 1999; Jaaska, 1999) and even in the very large cowpea gene pool, no such a high distance was recorded within a species (Pasquet, 1999). The wild and domesticated Kersting's groundnut differ in alternative alleles of Amp1, Amp2, Amp3, Dia, Est1, Est2, Est3, Fle1, Fle2, $\beta$ Glu1, $\beta$ Glu2, Got1, Idh, Mdh1, Mdh2, Me, Pgi1, and Sod2 (Table 2), i.e. at 18 loci out of 32 studied.

Therefore, although previously in our discussion we highlighted the parallel between both African geocarpic legume crops, Bambara groundnut and Kersting's groundnut, this parallel does not hold any more with respect to genetic differentiation between the wild and domesticated forms. In Bambara groundnut, the highest Nei (1972) distance recorded between wild and domesticated was 0.122, while the highest distance between two wild populations was 0.151 (Pasquet et al., 1999).

Consequently, the wild and cultivated taxa of the Kersting's groundnut should be better considered as two different species, although morphological differences between them are few. The domesticated taxon shows increased size in most organs, i.e. petioles and leaflets, flowers, pods and seeds, as well as shorter stem internodes and a higher number of ovules, but all these phenomena are also observed in Bambara groundnut. Unfortunately, as in the case of Hepper (1963), we were not able to observe flowers of the wild taxon. However, we can consider that floral structure is homogeneous in genus Macrotyloma (Verdcourt, 1982), and would not be so helpful. Above all, both taxa show a similar geocarpy through elongation of the stipe which turns into a root-like carpodium, and are the only ones to show it within genus Macrotyloma.

Difference in both taxa could be found in chromosome numbers. Hepper (1963) reported $2 n=20$ for the wild taxon, which is logical in genus Macrotyloma, while Miège (1962) reported $2 n=22$ for the domesticated taxon, but this really unusual count in genus Macrotyloma would need a confirmation. Of course, if this count will be confirmed, there would be no problem in separating both taxa at the species level.

Therefore, our results present the first important arguments to reinforce Verdcourt's (1982) suspicion that the wild and domesticated taxa of Kersting's groundnut belong to different species.

Considering both taxa as different species would mean that the wild progenitor of domesticated M. geocarpum is yet to be found. As no other Macrotyloma species shows a geocarpic fructification, this would mean that the progenitor is totally unknown, or that the progenitor is a species with classical fructification; therefore, two unlikely hypotheses. This situation is not unique regarding all domesticated plants. In Leguminosae, for example, wild progenitor of Vicia faba is still unknown. However, this seems to be a really unusual situation regarding the various African cultigens. With the absence of variability within cultivated material, this highlights the unique and very surprising features characterizing M. geocarpum (Harms) Maréchal and Baudet. 


\section{References}

Amuti, K., 1980. Geocarpa groundnut (Kerstingiella geocarpa) in Ghana. Econ. Bot. 34, 358-361.

Chevalier, A., 1910a. Sur une nouvelle légumineuse à fruits souterrains cultivée dans le moyen Dahomey (Voandzeia poissonii). C.R. Acad. Sci. 151, 84-86.

Chevalier, A., 1910b. Nouveaux documents sur le Voandzeia poissonii ou Kerstingiella geocarpa. C.R. Acad. Sci. 151, 1374-1376.

Chevalier, A., 1913. Kerstingiella (Kerstingiella geocarpa Harms). Veg. Util. Afr. Trop. 8, 358-361.

Crawford, D.J., 1989. Visualization and interpretation of plant isozymes. In: Soltis, P.S., Soltis, D.E. (Eds.), Isozymes in Plant Biology. Chapman and Hall, London, pp. 146-164.

Doebley, J., 1989. Isozymic evidence and the evolution of crop plants. In: Soltis, D.E., Soltis, P.S. (Eds.), Isozymes in Plant Biology. Chapman and Hall, London, pp. 165-191.

Harms, H., 1908. Über Geokarpie bei einer afrikanischen Leguminosae. Bericht. Deutsch. Bot. Gesellschaft 26, 225-231.

Hepper, F.N., 1963. The bambara groundnut (Voandzeia subterranea) and Kersting's groundnut (Kerstingiella geocarpa) wild in west Africa. Kew Bull. 16, 395-407.

Jaaska, V., 1999. Isoenzyme diversity and phylogenetic affinities among the African beans of the genus Vigna Savi (Fabaceae), Biochem. Syst. Ecol. 27, 569-589.

Kiang, Y.T., Chiang, Y.C., Doong, J.Y.H., Gorman, M.B., 1987. Genetic variation of soybean germplasm. In: Crop Exploration and Genetic Resources. Taichung District Agricultural Improvement Station, Taiwan, pp. 93-99.

Maréchal, R., Baudet, J.C., 1977. Transfert du genre africain Kerstingiella Harms à Macrotyloma (Wight and Arn.) Verdc. (Papilionaceae). Bull. Jard. Bot. Nat. Belg. 47, 49-52.

Mergeai, G., 1993. Influence des facteurs sociologiques sur la conservation des ressources phytogénétiques. Le cas de la lentille de terre (Macrotyloma geocarpum (Harms) Maréchal and Baudet) au Togo. Bull. Rech. Agron. Gembloux 28, 487-500.

Miège, J., 1962. Quatrième liste de nombres chromosomiques d'espèces d'Afrique occidentale. Rev. Cytol. Biol. Vég. 24, 149-164.

Nei, M., 1972. Genetic distance between populations. Am. Nat. 106, 283-292.

Nei, M., 1973. Analysis of gene diversity in subdivided populations. Proc. Natl. Acad. Sci. USA 70, 3321-3323.

Panella, L., Gepts, P., 1992. Genetic relationships within Vigna unguiculata (L.) Walp. based on isozyme analyses. Genet. Resour. Crop Evol. 39, 71-88.

Pasquet, R.S., Vanderborght, T., 1999. Isozyme polymorphism in some yellow- and blue-flowered Vigna species complexes (Fabaceae-Phaseoleae). Plant. Syst. Evol. 215, 1-20.

Pasquet, R.S., 1999. Genetic relationships among subspecies of Vigna unguiculata (L.) Walp. based on allozyme variation. Theor. Appl. Genet. 98, 1104-1119.

Pasquet, R.S., Schwedes, S., Gepts, P., 1999. Isozyme diversity in Bambara groundnut. Crop Sci. 39, 1228-1236.

Pellegrin, F., 1923. A propos de Kerstingiella tisserantii. Bull. Soc. Bot. Fr. 70, 491.

Potter, D., Doyle, J.J., 1992. Origins of the African yam bean (Sphenostylis stenocarpa, Leguminosae): evidence from morphology, isozymes, chloroplast DNA, and linguistics. Econ. Bot. 46, 276-292.

Schinkel, C., Gepts, P., 1989. Allozyme variability in the Tepary Bean, Phaseolus acutifolius A. Gray. Plant Breed 102, 182-195.

Singh, S.P., Nodari, R., Gepts, P., 1991. Genetic diversity in cultivated common bean: 1. Allozymes. Crop Sci. 31, 19-23.

Stapf, O., 1913. Kerstingiella geocarpa. Bull. Misc. Inf. Kew 1913, 93-94.

Tamini, Z., 1995. Etude ethnobotanique de la lentille de terre (Macrotyloma geocarpum Maréchal et Baudet) au Burkina Faso. J. Agric. Trad. Bot. Appl. 37, 187-199.

Vaillancourt, R.E., Weeden, N.F., 1993. Lack of isozyme similarity between Vigna unguiculata and other species of subgenus Vigna (Leguminosae). Can. J. Bot. 71, 586-591.

Vaillancourt, R.E., Weeden, N.F., Barnard, J., 1993. Isozyme diversity in the cowpea species complex. Crop Sci. 33, 606-613.

Verdcourt, B., 1978. The demise of two geocarpic legume genera. Taxon 27, 219-222. 
Verdcourt, B., 1982. A revision of Macrotyloma (Leguminosae). Hooker's Icon. Plant 38, 1-138.

Weeden, N.F., Wolko, B., Vaillancourt, R., 1996. Contrasting patterns of partitioning genetic diversity in cultivated legumes. In: Pickersgill, B., Lock, J.M. (Eds.), Advances in Legume Systematics 8: Legume of Economic Importance. Royal Botanic Gardens, Kew, pp. 1-9.

Wendel, J.F., Weeden, N.F., 1989. Visualization and interpretation of plant isozymes. In: Soltis, D.E., Soltis, P.S. (Eds.), Isozymes in Plant Biology. Chapman and Hall, London, pp. 5-45. 